\title{
KEBIJAKAN PEMERINTAH KABUPATENACEH JAYA DALAM PENGELOLAAN TAMBANG EMAS RAKYATDI GUNONG UJEUN
}

\author{
Aminah \\ Fakultas Ilmu Sosial Dan Ilmu Politik Universitas Teuku Umar \\ aminahaneukpanga@gmail.com
}

\begin{abstract}
This research aims to explain about the policy taken by the government of Aceh Jaya in the management of the people of the gold mine. The data that is required in writing is obtained through library research and field. Library research done with how to read text books, legislation, and other reading material related to this research. While field research done by interviewing informants. The results of the study showed that the policy of the government of Aceh Jaya in gold mining management people in Gunong Ujeun has not satisfied. This is because there are still many cases of illegal mining and still many communities miners do not know about: Perbup that has been set by the government. The district government of Aceh Jaya should work more maximum in preparing gold mine people to improve PAD.
\end{abstract}

Keywords: Policy, The Management of Natural Resources and Mining Gold People 


\section{PENDAHULUAN}

Kabupaten Aceh Jaya adalah salah satu kabupaten di provinsi Aceh, Indonesia. Kabupaten Aceh Jaya dibentuk sebagai hasil pemekaran dari Kabupaten Aceh Barat pada tanggal 22 Juli 2002. Kabupaten Aceh Jaya memiliki kekayaan alam yang beraneka ragam salah satu kekayaan alam yang dimiliki Kabupaten Aceh Jaya yaitu emas. Gunung Ujeun adalah salah satu lokasi tambang emas yang dikelola oleh masyarakat Kabupaten Aceh Jaya. Letaknya diapit oleh dua Kecamatanyaitu Kecamatan Krueng Sabee (Desa Panggong) dan Kecamatan Panga (Desa Batee Meutudong). Saat ini ada 1.200 hektar lahan yang sudahdieksploitasi untuk pertambangan emas rakyat. Warga yang datang dari sejumlah daerah membuat lubang-lubang hingga kedalaman puluhan meter untuk mencari emas yang terkandung di dalam bebatuan. Lokasi penambangan emas ini berjarak sekitar 30 kilometer dari pusat Kecamatan Krueng Sabee (Atjehpost.com, diunduh 28/08/ 2016).

Sebelum berlakunya otonomi daerah, pejabat yang berwenang memberikan izin kuasa pertambangan adalah Pemerintah Pusat, yang di wakili oleh Menteri Energi dan Sumber Daya Mineral. Dengan berlakunya otonomi daerah, kewenangan dalam pemberian izin tidak hanya menjadi kewenangan Menteri Energi dan Sumber Daya Mineral semata-mata, tetapi kini telah menjadi kewenangan Pemerintah Provinsi dan Kabupaten/Kota (Salim HS, 2006). Pejabat yang berwenang menerbitkan kuasa pertambangan adalah Menteri Energi dan Sumber Daya Mineral, Gubernur dan Bupati/Walikota sesuai dengan kewenangannya masing-masing. Hal ini sesuai Undang-Undang Republik Indonesia Nomor 11 Tahun 2006 Tentang Pemerintahan Aceh, Pasal 156 yang berbunyi "Pemerintah Aceh dan Pemerintahan Kabupaten/Kota mengelola sumber daya alam di Aceh baik di darat maupun di laut wilayah Aceh sesuai kewenangannya.Bupati/Walikota berwenang menerbitkan surat keputusan kuasa pertambangan, menandatangani kontrak karya, dan perjanjian karya pengusahaan pertambangan emas apabila wilayah kuasa pertambangan, kontrak karya, dan perjanjian karya pengusahaan pertambangan emas terletak dalam wilayah Kabupaten/Kota dan di wilayah laut sampai 4 mil laut (Salim HS, 2006: 3-4).

Sumber daya alam yang banyak terdapat di Kabupaten Aceh Jaya berupa kekayaan tambang, yaitu tambang emas menyebabkan banyak masyarakat baik dari kalangan masyarakat Kabupaten Aceh Jaya maupun masyarakat luar yang datang dari Kabupaten/Kota lainnya melakukan penambangan secara illegal di wilayah Gunong Ujeun, namun sampai saat ini Pemerintah Kabupaten Aceh Jaya belum mampu untuk menangani kasus tersebut. Permasalahan lain yang terjadi di lapangan yaitu sampai ini pertambangan emas Kabupaten Aceh Jayabelum mampu meningkatkan Pendapatan Asli Daerah (PAD) Aceh Jaya. Bahkan pada tahun 2010 Pemerintah Kabupaten Aceh Jaya belum menerima satu sen pun dana dari lokasi tambang emas tersebut yang masuk menjadi PAD Aceh Jaya. Hal ini disebabkan karena para penambang emas tidak memiliki izin resmi. Terkait hal tersebut Ketua DPRK Aceh Jaya, Tgk Hasan Ahmad dalam sebuah surat kabar menyatakan bahwa saat ini Pemerintah Kabupaten Aceh Jaya belum berani mengambil retribusi terhadap pertambangan emas karena belum ada aturan yang mengatur tentang itu. Jika pemerintah Kabupaten Aceh Jaya telah mengeluarkan peraturan atau kebijakan terhadap lokasi tambang emas tersebut baru Pemerintah bisa mengambil retribusi untuk selanjutnya dijadikan sebagai sumber PAD Pemerintah Kabupaten Aceh Jaya guna membangun daerah (Aceh Jaya Post, 2010).

Wakil Ketua DPRK Aceh Jaya, Suhelmi juga menyatakan tambang emas yang ada di Kabupaten Aceh Jaya tiada meski ada dan membenarkan bahwa selama ini belum ada sumbangan PAD dari tambang-tambang yang beroperasi di Kabupaten Aceh Jaya. Hal ini terbukti dari belum adanya izin yang dikeluarkan Pemerintah Kabupaten Aceh Jaya terhadap pertambangan tersebut. Jika para penambang sudah memiliki izin atau kebijakan sudah dikeluarkan oleh pemerintah Kabupaten Aceh Jaya tentu Pemerintah Kabupaten Aceh Jaya bisa mendapatkan PAD dari tambang tersebut (Buletin Parlementaria Aceh Jaya, 2011). Miris 
memang, jika dilihat dari sumber daya alam yang ada di Kabupaten Aceh Jayaseharusnya pemerintah Kabupaten Aceh Jaya mampu mengontrol praktek-praktek eksploitasi yang illegal yang terjadi di Gunong Ujeun dan mampu meningkatkan PAD Aceh Jaya dengan baik. Akan tetapi pada kenyataanya yang terjadi di lapangan dapat dilihat bahwa pemerintah Kabupaten Aceh Jaya sampai saat ini belum mampu mengontrol prktek-praktek eksploitasi yang illegal yang terjadi di Gunong Ujeun dan PAD Aceh Jaya semakin menurun dan bahkan tidak ada satu sen pun dari pertambangan emas yang masuk menjadi PAD Aceh Jaya.

Berdasarkan permasalahan diatas, tulisan ini mencoba untuk menganalisis apa yang menjadi penyebab pemerintah kabupaten Aceh Jaya tidak mendapatkan PAD dari hasil tambang Gunong Ujeun. Untuk dapat memberikan gambaran yang lebih jelas tentang ini, maka tulisan ini akan menjelaskantentang bagaimana kebijakan Pemerintah Kabupaten Aceh Jaya dalam pengelolaan pertambangan emas rakyat.

\section{METODOLOGI PENELITIAN}

Metode penelitian yang digunakan dalam penelitian adalah metode penelitian kualitatif dengan pendekatan studi kasus. Adapun yang menjadi lokasi penelitian ini adalah kabupaten Aceh Jaya, Provinsi Aceh, dengan pertimbangan bahwa, lokasi tersebut merupakan salah satu tempat yang memiliki kekayaan tambang berupa pertambangan emas yang harga jualnya tinggi serta dijadikan sebagai wilayah pertambangan rakyat yang dieksploitasi secara besar-besaran sejak tahun 2008 serta pemerintah daerah tidak menerima PAD dari hasil tambang emas rakyat tersebut.

Teknik pengumpulan data dilakukan melalui kepustakaan dan lapangan. Kepustakaan dengan membaca buku teks dan bahan bacaan lainnya yang berkaitan dengan tema penelitian sedangkan lapangan dengan mewawancarai para informan. Yang menjadi informan dalam penelitian ini adalah Kasie Pengusahaan Pertambangan Mineral Batubara dan Panas Bumi Dinas Pertambangan dan Energi Aceh, Kepala Bidang Pertambangan, Energi, dan Sumber Daya Mineral Kabupaten Aceh Jaya, Ketua Dewan Perwakilan Rakyat Kabupaten (DPRK) Aceh Jaya, Anggota DPRK Aceh Jaya Komisi Cbidang Pertambangan, Pihak Kecamatan Krueng Sabee, pihak kecamatan Panga, Kepala Desa (Geuchik) Gampong Batee Meutudong, Kepala Desa (Geuchik) Gampong Panggong, Anggota Koperasi pertambangan rakyat, Masyarakat penambang perseorangan, Ketua Koperasi Pertambangan Rakyat Peusahoe Rakan di Kecamatan Krueng Sabee, Ketua Koperasi Pertambangan Rakyat Aceh Sumatra di Kecamatan Panga. Sedangkan teknik analisis data yaitu Proses analisis data dimulai dengan menelaah seluruh data yang tersedia dari berbagai sumber, setelah menelaah langkah berikutnya yaitu mereduksi data dengan melakukan abstraksi atau membuat rangkuman inti. Tahap ketiga yaitu menyusun datadata tersebut dalam satuan-satuan dan tahap akhir dari analisis data ialah melakukan pemeriksaan keabsahan data (Moleong, 2012).

\section{PEMBAHASAN}

Emas yang terdapat di wilayah Gunong Ujeun kabupaten Aceh Jaya memiliki banyak manfaat, terutama bagi masyarakat yang melakukan penambangan, hal ini menyebabkan pengekploitasi tambang emas tersebut secara besar-besaran semakin lama semakin marak terjadi. Banyak masyarakat dari sejumlah daerah datang ke lokasi Gunong Ujeun untuk bekerja sebagai para penambang terutama dari wilayah pulau Jawa dan kabupaten/kota lainnya baik yang bergabung dengan koperasi yang ada di kecamatan Panga dan Kecamatan Krueng Sabee maupun bekerja secara individu (tidak bergabung dengan Koperasi).Meskipun Aceh Jaya memiliki kekayaan alam yang beraneka ragam seperti emas yang harga jualnya sangat tinggi namun sampai saat ini pemerintah kabupaten Aceh Jaya belum menerima pendapatan asli daerah dari hasil tambang emas tersebut. 
Pemerintah kabupaten Aceh Jaya memiliki kewajiban untuk membuat peraturan atau kebijakan yang mengatur tentang pertambangan emas yang ada di wilayah kabupaten Aceh Jaya mulai dari merumuskan, menetapkan dan mengimplementasikan kebijakan tersebut agar pemerintah Aceh Jaya menerima pendapatan asli daerah dari hasil tambang emas yang ada di Gunong Ujeun. Terkait hal tersebut pemerintah kabupaten Aceh Jaya telah mengeluarkan Peraturan Bupati (Perbup) Aceh Jaya Nomor 21 Tahun 2011 tentang Penataan Pertambangan Rakyat. Dalam Perbup tersebut telah banyak aturan-aturan yang harus diikuti oleh para pelaku atau masyarakat yang melakukan penambangan emas rakyat di Gunong Ujeun. Salah satu point yang sangat penting dalam Perbup tersebut adalah mengenai hak dan kewajiban yaitu setiap orang perseorangan, kelompok masyarakat atau Koperasi mempunyai hak dan dapat mengajukan permohonan Izin Pertambangan Rakyat (IPR) pada lokasi baru apabila telah memenuhi kewajiban sesuai dengan aturan yang berlaku. Selain itu, dalam Perbup tersebut juga menjelaskan tentang distribusi yang harus dibayarkan oleh pihak orang perseorangan, kelompok atau Koperasi. "membayar sumbangan pihak ketiga sesuai dengan aturan perundang-undangan yang berlaku". Selanjutnya orang perseorangan juga harus menyampaikan laporan bulanan, triwulan dan tahunan tentang perkembangan kegiatan pertambangan rakyat dan kegiatan lainnya yang berkaitan dengan pertambangan kepada Bupati Aceh Jaya melalui bidang pertambangan.

Namun,meskipun pemerintah kabupaten Aceh Jaya telah menetapkan berbagai peraturan dan persyaratan secara detail terhadap para masyarakat yang melakukan penambangan emas rakyat di Gunong Ujeun, kebijakan tersebut tetap tidak dapat berjalan dengan baik apabila pihak pemerintah Kabupaten Aceh Jaya kurang melakukan sosialisasi terhadap perbup atau kebijakan yang telah ditetapkan. Seperti yang dijelaskan oleh (Khairil Basyar, Kasie Pengusahaan Pertambangan Mineral Batubaradan Panas Bumi Dinas Pertambangan dan Energi Aceh, wawancara,30Maret 2016)"pihak pemerintah Kabupaten Aceh Jaya kurang melakukan sosialisasi kepada masyarakat, sehingga sebagian masyarakat yang melakukan penambangan emas tidak mengetahui akan adanya perbup yang telah ditetapkan".

Selain itu, pemerintah Kabupaten Aceh Jaya dalam melakukan pengelolaan pertambangan emas di Gunong Ujeun juga harus mendapatkan berbagai bentuk dukungan, baik dari jajaran pemerintah kabupaten Aceh Jaya sendiri maupun dari masyarakat penambangan emas rakyat. Dalam hal ini Bupati beserta jajarannya melakukan pengelolaan tambang emas dengan baik seperti mengesahkan Qanun dan Perbup terkait penataan pertambangan, mensosialisasikan serta mengimplementasikan aturan-aturan yang telah dibentuk.Sehingga dengan adanya langkahlangkah penataan pertambangan emas rakyat, lokasi pertambangan emas rakyat akan lebih tertata secara rapi dan pemerintah juga akan mendapatkan PAD dari hasil tambang tersebut.

Penambangan yang dilakukan oleh masyarakat di lokasi tambang emas Gunong Ujeun masih bersifat ilegal.Hal ini disebabkan karena masih terkendala dengan kawasan atau wilayah hutan produksi. Adapun peta pertambangan emas rakyat di wilayah Gunong Ujeun dapat dilihat pada gambar dibawah ini:

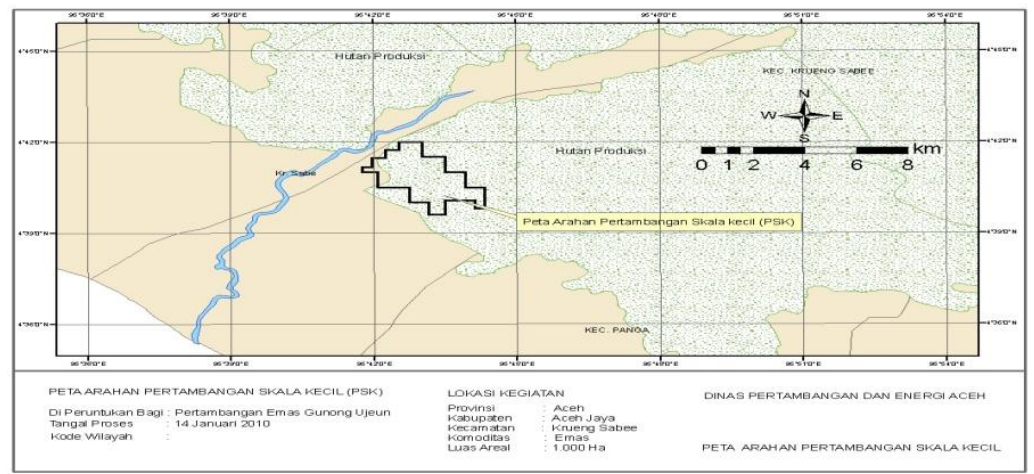

Gambar 1. Peta Wilayah Pertambangan Emas Rakyat 
Peta diatas menunjukkan bahwa hampir seluruh area wilayah pertambangan yang mendapatkan rekomendasi dari Gubernur Aceh pada tahun 2010 merupakan wilayah hutan produksi, yang hingga saat ini belum mendapatkan izin dari pihak Dinas Kehutanan Kabupaten Aceh Jaya dan dari Menteri Kehutanan Republik Indonesia untuk dijadikan wilayah tersebut sebagai wilayah pertambangan rakyat.Saat ini pihak Dinas Kehutanan Kabupaten Aceh Jaya masih menunggu perijinan dari pihak pusat dan wilayah tersebut masih dalam proses pembebasan kawasan.Terkait hal tersebut, Irwansyah (Kabid Pertambangan ESDM Dinas Pekerjaan Umum Kabupaten Aceh Jaya, wawancara, 10Maret 2016) menjelaskan bahwa "penambangan yang dilakukan oleh masyarakat di lokasi tambang emas Gunong Ujeun masih bersifat ilegal karena masih terkendala dengan kawasan hutan produksi. Yang berhak memberikan izin usaha untuk melakukan pertambangan adalah kami (Pertambangan ESDM Dinas Pekerjaan Umum Kabupaten Aceh Jaya) tapi untuk urusan pembebasan lahan harus mendapatkan izin pembebasan dari Menteri Kehutanan Republik Indonesia dan hingga saat ini masih dalam proses pembebasan kawasan tersebut".

Berbeda dengan pihak Dinas dan Kabid ESDM, pihak Dewan Perwakilan Rakyat Kabupaten (DPRK) Aceh Jaya dalam pengelolaan pertambangan emas rakyat di Gunong Ujeun kecamatan Krueng Sabee hingga saat ini terus mencari solusi dan sedang menunggu pengesahan Qanun provinsi tentang pertambangan energi dan sumber daya mineral sehingga dapat merancang Qanun kabupaten yang berkaitan dengan pertambangan emas rakyat. Namun sampai saat ini DPRK Aceh Jaya belum bisa merancang Qanun tersebut disebabkan belum adanya Qanun Provinsi. Karena jika Qanun Provinsi belum disahkan maka Qanun kabupaten tidak dapat dirancang karena ditakutkan akan bertentangan dengan aturan yang ditetapkan oleh provinsi. Selain itu pemerintah Kabupaten Aceh Jaya akan mengfungsikan WPR. Ketika masyarakat sudah bisa mengambil hasil dari pertambangan emas, tentu pemerintah Kabupaten Aceh Jaya juga dapat mengambil retribusi dari setiap warga penambang yang nantinya akan menjadi PAD bagi Kabupaten Aceh Jaya(Hasan Ahmad, Ketua DPRK Aceh Jaya, wawancara, 03 Desember 2013).

DPRK Aceh Jaya sebagai lembaga perwakilan rakyat seharusnya dapat mengupayakan terbentuknya suatu peraturan atau Qanun yang tegas dan mengikat bagi setiap individu atau kelompok koperasi penambangan emas yang bekerja di wilayah Gunong Ujeun, dalam hal ini peraturan yang ditetapkan dapat memuat ketentuan yang tegas dan mengikat mengenai persyaratan, larangan dan sanksi bagi setiap individu atau koperasi yang hendak melakukan penambangan emas, sehingga kegiatan penambangan emas di wilayah pertambangan tersebut dapat berjalan sesuai dengan prosedur dan pemerintah kabupaten Aceh Jaya dapat mengutip pajak atau iuran wajib dari setiap para penambang untuk meningkatkan pendapatan asli daerah kabupaten Aceh Jaya(Ibnu Sakdan, Anggota DPRK Aceh Jaya Komisi C Bidang Pertambangan, wawancara, 10April 2016).

Alasan para pernambang emas tidak memberikan iuran kepada pihak pemerintah karena masyarakan melakukan penambangan emas rakyat tersebut atas inisiatifnya sendiri, seperti yang dijelaskan oleh Jullasmi(Anggota Koperasi dari Pertambangan Rakyat Peusahoe Rakan, wawancara, 12April 2016) "mereka membangun jalan menuju lokasi tambang emas dari modal masyarakat tanpa adanya ikut campur atau mendapatkan bantuan dari pemerintah kabupaten. Oleh karena itu pemerintah kabupaten Aceh Jaya tidak dapat mengambil iuran dari masyarakat karena belum ada peraturan yang jelas".

Salah satu bentuk kebijakan pemerintah Aceh Jaya yang sudah dapat dijalankan di kabupaten Aceh Jaya tekait tambang emas rakyat yaitu pemerintah menghimbau kepada seluruh masyarakat penambang emas Gunong Ujeun kecamatan Krueng Sabee supaya bergabung dengan koperasi-koperasi baik masyarakat lokal (asli) kabupaten Aceh Jaya maupun masyarakat yang datang dari kabupaten/kota lain atau tenaga kerja luar. Masyarakat yang datang dari kabupaten/kota lain atau tenaga kerja luar yang melakukan penambangan di wilayah Gunong 
Ujeun kecamatan Krueng Sabee harus bergabung dengan koperasi yang telah dibentuk di dua kecamatan yaitu kecamatan Krueng Sabee dan kecamatan Panga yang didalamnya sudah terbentuk sebanyak 19 koperasi pertambangan rakyat yaitu 11 Koperasi Pertambangan Rakyat di kecamatan Krueng Sabee dan 8 Koperasi Pertambangan Rakyat di kecamatan Panga. Dengan adanya koperasi pertambangan rakyat, masyarakat dapat bekerja secara legal tanpa adanya gangguan serta dapat memudahkan transportasi masyarakat jika terjadi hal-hal yang tidak diinginkan.

Dari pihak kecamatan, baik kecamatan Panga maupun kecamatan Krueng Sabee tidak membuat suatu kebijakan ataupun himbauan kepada masyarakat penambang. Pihak kecamatan hanya memberikan rekomendasi kepada masyarakat yang ingin bergabung dengan koperasikoperasi yang telah dibentuk. Sebagai pelayan masyarakat ditingkat kecamatan, pihak pemerintah kecamatan Panga dan Krueng Sabee meneruskan apapun yang telah ditetapkan oleh pihak pemerintah Kabupaten Aceh Jaya. Selain memberikan rekomendasi kepada masyarakat pihak kecamatan juga pernah melakukan survey secara langsung ke lokasi penambangan emas di Gunong Ujeun. Terutama pada saat musibah longsor yang terjadi pada beberapa waktu lalu yang mengakibatkan tewasnya beberapa orang masyarakat penambang.

Lain halnya di Gampong Panggong, pihak aparatur gampong telah sepakat untuk membentuk peraturan atau Qanun Gampong. Dalam Qanun Gampong tersebut memuat aturanaturan yang harus dipatuhi oleh para penambang. Salah satu point dari Qanun Gampong tersebut adalah "bagi setiap para penambang yang membawa turun batu galian emas wajib memberikan kepada pihak gampong Panggong sebanyak 1 tempurung (bruek). Namun sampai saat ini peraturan tersebut sudah tidak diberlakukan lagi karena wilayah tersebut dinyatakan ilegal oleh pemerintah" (Tgk. Yusman, Geuchik Gampong Panggong kecamatan Krueng Sabee, wawancara, 12 Maret 2016). Meskipun pihak gampong telah menetapkan Qanun, namun Qanun tersebut hanya dapat dijalankan selama 2 tahun, dan sampai saat ini penambangan emas tersebut terus dilakukan oleh masyarakat yang datang dari sejumlah daerah dengan melakukan penambangan secara ilegal tanpa adanya suatu bentuk teguran dari pihak manapun. Sedangkan di Gampong Batee Meutudong tidak membuat peraturan (Qanun) Gampong apapun terkait tambang emas di Gunong Ujeun.

Sebahagian besar masyarakat kabupaten Aceh Jaya juga sangat mendukung kebijakan pemerintah kabupaten Aceh Jaya dalam membentuk koperasi-koperasi pertambangan emas rakyat, seperti yang diungkapkan oleh beberapa masyarakat yang bergabung dengan koperasi, yaitu:"Kami sangat mendukung kebijakan yang dikeluarkan oleh pemerintah kabupaten Aceh Jaya karena sebahagian besar masyarakat yang melakukan penambangan di Gunong Ujeun mau bergabung di koperasi-koperasi pertambangan rakyat yang telah dibentuk baik masyarakat pribumi maupun masyarakat pendatang dari sejumlah daerah lainnya. (Jullasmi,Anggota Koperasi dari Pertambangan Rakyat Peusahoe Rakan, wawancara,10April 2016).

Sebahagian masyarakat penambang kabupaten Aceh Jaya juga ada yang tidak mendukung kebijakan yang telah ditetapkan oleh pemerintah. Bentuk masyarakat yang tidak mendukung yaitu masyarakat tidak mau bergabung dengan koperasi-koperasi. Hal ini disebabkan karena kurangnya pemahaman masyarakat tentang guna mereka ikut bergabung dengan koperasi sehingga mereka lebih memilih untuk melakukan penambangan secara tradisional atau secara individu di lokasi pertambangan. seperti yang diucapkan oleh beberapa masyarakat yang tidak bergabung dengan koperasi yaitu: "Pemerintah Aceh Jaya kurang melakukan sosialisasi kepada kami. Alasan kami lebih memilih untuk tidak ikut bargabung dengan koperasi pertambangan rakyat karena jika kami ikut bergabung dengan koperasi kami dituntut membayar iuran-iuran kepada setiap koperasi yang akan kami ikuti" (Syarifuddin, Masyarakat Penambangan emas, wawancara, 10 April 2016)). Pemerintah Kabupaten Aceh Jaya setelah mengeluarkan Perbup Aceh Jaya Nomor 21 Tahun 2011 tentang Penataan Pertambangan Rakyat seharusnya melakukan sosialisasi dan memberikan pemahaman kepada seluruh masyarakat penambang 
emas rakyat tentang isi Perbup tersebut karena dengan adanya sosialisasi masyarakat lebih mengerti tentang apa saja peraturan yang telah dikeluarkan oleh pemerintah. Jika Pemerintah kurang melakukan pengelolaan dan pengawasan terhadap pertambangan emas rakyat tersebut, Pemerintah Kabupaten Aceh Jaya harus siap untuk kehilangan aset daerah secara sia-sia tanpa adanya manfaat yang dirasakan oleh seluruh masyarakat Kabupaten Aceh Jaya.

\section{SIMPULAN}

Kebijakan Pemerintah Kabupaten Aceh Jaya dalam pengelolaan pertambangan emas rakyat yaitu Pemerintah Kabupaten Aceh Jaya telah mengeluarkan suatu Perbup yang mengatur tentang pengelolaan pertambangan emas rakyat. Salah satu butir isi dari Perbup tersebut adalah masyarakat penambangan emas dari dua Kecamatan yaitu Kecamatan Krueng Sabee dan Kecamatan Panga dapat membentuk Koperasi Pertambangan Rakyat namun Pemerintah Kabupaten Aceh Jaya kurang melakukan sosialisasi terhadap Perbup tersebut sehingga banyak masyarakat yang tidak mengetahui bahwa pemerintah telah mengeluarkan peraturan yang mengatur tentang pertambangan emas rakyat. Selain itu DPRK Aceh Jaya sedang menunggu pengesahan Qanun Provinsi yang mengatur tentang Pertambangan dan energi sumber daya mineral sehingga Qanun kabupaten Aceh Jaya belum dapat dibentuk karena ditakutkan akan bertentangan dengan Qanun provinsi. Untuk meningkatkan PAD, Kabupaten Aceh Jaya harus melakukan berbagai penataan terhadap pertambangan emas rakyat Di Gunong Ujeun terutama harus mengimplementasikan peraturan-peraturan yang telah ditetapkan oleh pemerintah Kabupaten Aceh Jaya.

\section{REFERENSI}

AG, Subarsono. 2006. Analisis Kebijakan Publik: Konsep, Teori dan Aplikasi. Yogyakarta: Pustaka Pelajar.

AG, Subarsono. 2007. Akuntansi Sektor Publik Akuntansi keuangan daerah. Edisi Revisi. Jakarta: Salemba Empat.

Bastian, Indra. 2002.Sistem Akuntansi Sektor Publik. Buku 1 Jakarta: Salemba Empat.

Budiardjo, Miriam. 2008. Dasar,-Dasar Ilmu Politik. Gramedia: Pustaka Utama Halim Abdul. 2004. Akuntansi Keuangan Daerah. Jakarta: Salemba Empat.

HS, Salim. 2006. Hukum Pertambangan di Indonesia. Jakarta: PT Raja GrafindoPersada. Moleong. 2002. Metodologi Penelitian Kualitatif Edisi Revisi. Bandung: PT. Remaja Rosdakarya. 2007.Metodologi Penelitian Kualitatif Edisi Revisi, Bandung: PT. Remaja. Rosdakarya. 2012.Metodologi Penelitian Kualitatif Edisi Revisi. Bandung: PT. Remaja. Yani, Ahmad. 2002.Hubungan Keuangan Antara Pemerintah Pusat dan Daerah di Indone. Jakarta: Raja Grafindo Persada.

Zainal, Said Abidin. 2004. Kebijakan Publik. Jakarta: Yayasan Pancur Siwah.

Aceh Jaya Post. Edisi VI Tahun 2010

Buletin Parlementaria Aceh Jaya Edisi III tahun 2011

Darmansyah Muda. Bertaruh Nasib Di Tambang Emas Gunung Ujeuen. Atjeh Post. Oktober. 2012. di akses pada hari Senin, 3 Oktober $2016 \mathrm{Jam}$ 20:01 WIB di http://Atjehpost.Com/Read/2012/10/18/24674/83/3/Bertaruh-NasibDi-Tambang-Emas-Gunung-Ujeuen.

Kabupaten Aceh Jaya. Selamat Datang di Website Aceh Jaya, di akses pada hari Senin, 3 Oktober 2016 Jam 20:10 WIB di http://www.acehjayakab.go.id.

Undang-Undang Dasar 1945

Undang-Undang Nomor 22 Tahun 1999 tentang Pemerintahan Daerah

Undang-Undang Nomor 25 Tahun 1999 Tentang Pemerintah Daerah 
Undang-Undang Nomor 4 Tahun 2002 Tentang Pembentukan Kabupaten Aceh Barat Daya, Kabupaten Gayo Lues, Kabupaten Aceh Jaya, Kabupaten Nagan Raya, Dan Kabupaten Aceh Tamiang, Di Provinsi Nanggroe Aceh Darussalam.

Undang-Undang Nomor 33 Tahun 2004 Tentang Perimbangan Keuangan antara Pemerintah Pusat dan Pemerintahan Daerah

Undang-Undang Republik Indonesia Nomor 11 Tahun 2006 Tentang Pemerintahan Aceh

Qanun Provinsi Nanggroe Aceh Darussalam Nomor 12 Tahun 2002 Tentang Pertambangan Umum, Minyak dan Gas Alam.

Peraturan Bupati Aceh Jaya Nomor 21 Tahun 2011 tentang Penataan Pertambangan Rakyat 